\title{
FERMENTATION AND NUTRITIVE VALUE OF SILAGE AND HAY MADE FROM THE AERIAL PART OF CASSAVA (Manihot esculenta Crantz)
}

\author{
Eduardo Zambello de Pinho ${ }^{1 *}$; Ciniro Costa $^{1}$; Mario De Beni Arrigoni ${ }^{1}$; Antonio Carlos Silveira ${ }^{1}$; \\ Carlos Roberto Padovani²; Sheila Zambello de Pinho \\ ${ }^{1}$ UNESP/FMVZ - Depto. de Melhoramento e Nutrição Animal, C.P. 560 - 18618-000 - Botucatu, SP - Brasil. \\ ${ }^{2}$ UNESP/IB - Depto. de Bioestatística, C.P. 510 - 18618-000 - Botucatu, SP - Brasil. \\ *Corresponding author <eptrevo@terra.com.br>
}

\begin{abstract}
Cassava (Manihot esculenta Crantz), although native to Brazil, is still underutilized, especially when it comes to using its aerial part. In order to study the potential of the cassava plant for use as animal feed, the present work evaluated the characteristics of the aerial part of cassava when submitted to the processes of ensiling and haymaking. Treatments consisted of: aerial part of the plant ensiled without wilting (PAS); aerial part ensiled after wilting (PAE), and aerial part made into hay (PAF). Chemical analyses were run in order to evaluate the traits that determine the nutritional value of silage and hay. Wilting increased dry matter concentration from $25 \%$ to $27.7 \%$, without changing the concentration of soluble carbohydrates (33.3 and 35.5\% in the PAS and PAE, respectively), as well as buffer capacity (204 mmol kg ${ }^{-1} \mathrm{DM}$ in PAS and $195 \mathrm{mmol} \mathrm{kg}^{-1} \mathrm{DM}$ in PAE). Neither $\mathrm{pH}$ (3.57 in fresh silage and 3.60 in PAE) nor the ADIN concentration (11.32\% of total nitrogen in PAS and 9.99\% of total nitrogen in PAE) differed between the silages, but ADIN concentration was higher in hay (15.39\%). Wilting caused an increase in the concentration of ammonia (from $6.5 \%$ of total nitrogen in PAS to 13.0 of total nitrogen in PAE). The levels of volatile fatty acids did not change with wilting. The ensiling process reduced the concentrations of free hydrocyanide (HCN), without, however, affecting cyanohydrin.
\end{abstract}

Key words: hydrocyanic acid, nutritional composition, preservation

\section{PADRÃO DE FERMENTAÇÃO E VALOR NUTRITIVO DAS SILAGENS E DO FENO DA PARTE AÉREA DE MANDIOCA (Manihot esculenta Crantz)}

\begin{abstract}
RESUMO: A mandioca, apesar de ser nativa do Brasil, ainda é sub-utilizada principalmente quando a questão é o aproveitamento da sua parte aérea. Com o objetivo de estudar o potencial da mandioca para alimentação animal, o presente trabalho avaliou as características da parte aérea da planta quando submetida os processos de ensilagem e fenação. Os tratamentos consistiram de: parte aérea ensilada sem emurchecimento (PAS); parte aérea ensilada após 24 horas de emurchecimento (PAE) e parte aérea fenada (PAF). As análises químicas foram realizadas a fim de avaliar os parâmetros que determinam o valor nutritivo da silagem e do feno. O emurchecimento elevou o teor de matéria seca de $25 \%$ no material in natura para $27.7 \%$, sem alterar o teor de carboidratos solúveis (33.3 e 35.5\% de MS na PAS e PAE respectivamente), bem como o poder tampão (204 mmol kg-1 MS na PAS e $195 \mathrm{mmol} \mathrm{kg}^{-1} \mathrm{MS}$ na PAE). Nem o pH (3.57 na silagem in natura e 3.60 na PAE) nem os teores de NIDA (11.32\% do nitrogênio total na MS na PAS e $9.99 \%$ do nitrogênio total na MS na PAE) diferiram entre as silagens, mas o NIDA foi maior na forragem fenada (15.39\%). Contudo, o emurchecimento provocou aumento no nitrogênio amoniacal (de 6.5\% do nitrogênio total na MS da PAS para 13.0 do nitrogênio total na MS da PAE). Os teores de ácidos graxos voláteis não sofreram alterações com o emurchecimento. O processo de ensilagem reduziu os teores de ácido cianídrico livre (HCN), sem, contudo, alterar a cianidrina.

Palavras-chave: ácido cianídrico, composição bromatológica, conservação
\end{abstract}

\section{INTRODUCTION}

In Brazil cassava is a very important crop from a social and economic standpoint, since it can be found throughout the country. In addition to the fact that the country is a worldwide producer of roots, the cassava crop in Brazil ranks second in planted area, coming af- ter maize (Zea mays L.), which is the country's main crop. Cassava also plays an important social role in generating employment, thus helping small properties to become viable in the nation (FNP Consultoria e Comércio, 2002).

Cassava is a species native to Brazil, belonging to the genus Manihot with over 200 species Manihot 
esculenta Crantz. is the most important species of the genus in the country but, so far little is known about this crop, which has been underutilized in this country, in view of the fact that only the roots are explored by growers and processing enterprises (Carvalho 1990).

Growers commonly use a harvest index (HI), which is the ratio between the dry weights of aboveground aerial part of the plant and that of its root system (Conceição, 1981). The HI varies among cultivars, crop stages and edaphic-climatic conditions, and indicates the participation percentage of the roots in the entire plant. The first reports of cassava use in animal nutrition were made by D'Utra (1899) on the intake of plant leaves by domestic animals.

The main obstacle for the use of cassava in animal nutrition is the toxic principle the plant contains; intoxication reports are fairly common (Batistini et al., 1981) when the producer does not use some sort of treatment in plant parts to eliminate or mitigate its effects. Buitrago (1990) reported dehydration and heating as methods for the elimination of hydrocyanic acid (HCN) in cassava. Buitrago (1990) also reported ensiling as another process that decreases the HCN potential in the roots, reducing the toxic principle by about $63 \%$.

The present work had the objective of identifying to alternatives for the use of the cassava plant, which is often underutilized because of a lack of knowledge about its potential or technical and culture-related misconceptions. The use of its byproducts in animal feeding could be an alternative for both the farmer that subsists on this crop and for the industry. Considering the fact that cassava is cultivated all over Brazil and is important to small-scale farmers, research efforts are needed to find means of optimizing its use.

\section{MATERIALAND METHODS}

The experiment was conducted in Botucatu, SP, Brazil (2240'31"S, 48²5'37"W, altitude $770 \mathrm{~m}$ ). The cassava variety used was Branca de Santa Catarina, at a maturity of 12 to 13 months after planting, and harvested in the first half of December, 2000. The climatic conditions during the experimental period were: $22^{\circ} \mathrm{C}$ mean temperature; $5.10 \mathrm{~h}$ of solar bright and $4.04 \mathrm{~mm}$ precipitation per day.

The experimental design was completely randomized with three treatments and eight replications. The treatments consisted of three forms of preservation (ensiling and haymaking): Cassava aerial part ensiled without wilting (EWW); Cassava aerial part ensiled after wilting (EAW); and Cassava aerial part preserved by haymaking process (HAY). To evaluate the loss of the HCN toxic principle due to the fermentation process and eventual losses in nutritive value, samples were analyzed for chemical composition.
The above-ground mass of the cassava crop was cut at $20 \mathrm{~cm}$ at $8 \mathrm{~h} 00$. The material to be ensiled was first ground in a hammer mill. The material to be wilted was spread on a concrete surface outdoors for 24h, after which it was also passed through a hammer mill. The material to be dehydrated for hay was also ground before it was spread out on plastic tarp during the day and raked up at night, until dehydration was complete.

The experimental silos consisted of double-layered plastic bags with approximately 20 L capacity, and the material was compacted manually. The silos were opened after 30 days of storage. The forage was chopped with a tractor-powered silage chopper, which produced particles with size ranging from 15 to $20 \mathrm{~mm}$. Samples were taken during grinding; part of the samples were frozen at $-20^{\circ} \mathrm{C}$, while another part was pre-dried in a forced air circulation oven at $60^{\circ} \mathrm{C}$ until constant weight. The frozen material was used for total soluble carbohydrate analysis, according to the technique proposed by Dubois et al. (1956).

The buffer capacity to hydrochloric acid was quantified in the wilted material according to the method of Playne \& McDonald (1966), adapted by Tosi (1973); the nutritive value was also quantified in terms of the concentrations dry matter (DM), crude protein (CP), crude fiber (CF), ether extract (EE), ash (ASH), and soluble nitrogen (Nsol.), using methods proposed by Silva (1981); "in vitro" true digestibility (IVTD) was analyzed according to the method of Van Soest (1994), while the concentrations of neutral detergent fiber (NDF), acid detergent fiber (ADF), cellulose, lignin and acid detergent insoluble nitrogen (ADIN) were determined according to Van Soest (1994).

TDN (total digestible nutrients) concentration was estimated using Kearl's equation (Kearl, 1971). Samples were also taken before and after ensiling for analysis of total and free hydrocyanic acid concentration, using the method described by Essers et al. (1993). Four whole plants were collected and their fresh weight was determined to characterize their different plant part proportions. Harvest index (HI) was calculated by dividing root weight by whole plant weight (fresh weight). Leaf-stem (L/S) ratio was obtained by dividing leaf weight by stem weight (fresh weight). Due to the cyclic behavior of the cassava plant, these characteristics are highly variable and can change from year to year or even during a given year. Statistical analyses were not performed for $\mathrm{HI}$ or for the L/S ratio, as these are forms of better characterizing the material used in the experiment, but do not interfere with the central discussion of the work.

The samples taken from the silos were filter pressed to extract the juice from the silages, which were 
used to determine $\mathrm{pH}$, ammonia-nitrogen as total nitrogen percentage (Tosi, 1973), and acetic, propionic, butyric and lactic acids, measured in a gas chromatograph, according to methodology described by Wilkins et al. (1971), with modifications by Boin (1975).

An analysis of variance was run and treatment means were compared by Tukey test at the $1 \%$ level (Mischan \& Pinho, 1996).

\section{RESULTS AND DISCUSSION}

HI values averaged 73.3 and $67.9 \%$ respectively, for dry and wet weight, thus placing this material at the upper limit for this parameter, according to CIAT (1974). HI values range from 33.8 up to $67.8 \%$ in the original matter.

The analysis of the aerial part of cassava (Table 1) showed that the proportion of stems and original stem cuttings did not differ $(P>0.01$, mean $=11,6 \%)$; the stem cutting did not take part in the ensiling process, especially because it had high fiber concentration.

In spite of being an aid in characterizing the nutritive value of forages, the leaf/stem ratio (L/S) is not utilized for such characterization in cassava, mainly because research papers dealing with this issue are scarce. Nonetheless, it is still used in animal nutrition, studies with little scientific support, partly because. L/S varies cyclicly in cassava. The species can be classified as deciduous in regions that have a well-defined winter (Carvalho, 1990). L/S is important in the study of the protein concentration of above-ground parts of the plant, because leaves have the highest amino acid concentrations in cassava (Normanha, 1966). The material used in the experiment showed a value of 0.3 for L/S (leaves with petioles).

With regard to the proportion that each part represents in the dry weight of the plant (Table 1), a greater participation of the root system was found (73.3\%) in relation to the aerial part (26.6\%), as also evidenced by HI. The plant parts showing the smallest dry matter concentrations were stems (24.5\% DM) and leaves (27.2 $\% \mathrm{DM})$. The roots revealed a greater dry matter concentration in the cassava plant (36.7\%).
From the chemical composition data (Table 2), wilting did not change $\mathrm{CP}$ and EE concentration. The protein concentration in the aerial part was not affected by the treatments, with a mean of value $7.76 \%$, comparable to silages from traditional forages such as maize, as reported by Silveira (1975) and Creste (2000). The material made into hay (PAF) showed higher CF and MM concentrations, as well as higher ADF and NDF concentration (Table 3), than the non-wilted and wilted materials, suggesting a high degree of oxidation, of soluble substances when the aerial part of cassava undergoes wilting or is made into hay due to tissue respiration. In addition, the wilting process can also cause loss of leaves without, however, adding any advantages to the fermentation process.

Table 1 - Plant part percentages and their respective dry matter concentrations (DM).

\begin{tabular}{lcc}
\hline Plant part & \% of plant (dry weight) & DM \\
\hline & & $\%$ \\
Leaves & 3.45 & 27.25 \\
Stem & 11.39 & 24.54 \\
Original stem cutting & 11.84 & 32.53 \\
Root & 73.32 & 36.72 \\
Whole plant & 100 & 33.70 \\
\hline
\end{tabular}

Table 2 - Dry matter (DM), crude protein (CP), crude fiber (CF), ether extract (EE) and mineral matter (MM) concentrations of non-wilted (PAS), wilted (PAE), and hayed (PAF) aerial part of cassava plants.

\begin{tabular}{|c|c|c|c|c|}
\hline & \multicolumn{3}{|c|}{ Treatment } & \multirow{2}{*}{$\mathrm{CV}$} \\
\hline & PAS & PAE & PAF & \\
\hline & $-1-1-1$ & \% & . & 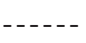 \\
\hline DM & $25.0 \pm 0.76 \mathrm{c}^{*}$ & $27.7 \pm 0.36 b$ & $90.9 \pm 0.30 \mathrm{a}$ & 1.07 \\
\hline $\mathrm{CP}$ & $7.98 \pm 0.73 \mathrm{a}$ & $7.39 \pm 0.51 \mathrm{a}$ & $7.92 \pm 0.55 \mathrm{a}$ & 7.79 \\
\hline $\mathrm{CF}$ & $29.5 \pm 0.78 \mathrm{ab}$ & $29.2 \pm 1.16 b$ & $30.5 \pm 0.95 a$ & 1.09 \\
\hline EE & $3.50 \pm 0.44 \mathrm{a}$ & $3.68 \pm 0.54 \mathrm{a}$ & $3.91 \pm 0.19 \mathrm{a}$ & 11.28 \\
\hline $1 \mathrm{M}$ & $3.91 \pm 0.19 b$ & $4.40 \pm 0.26 \mathrm{a}$ & $4.84 \pm 0.43 a$ & 3.33 \\
\hline
\end{tabular}

Means followed by the same lower case letter in the row are not different by Tukey test $(P<0.01)$.

$*$ Mean \pm standard deviation

Table 3 - Neutral detergent fiber (NDF\%), acid detergent fiber (ADF\%), cellulose and lignin in the non-wilted ensiled aerial part (PAS), wilted ensiled aerial part (PAE) and hayed aerial part (PAF\%) of cassava plants.

\begin{tabular}{lcccc}
\hline Treatment & NDF & ADF & Cellulose & Lignin \\
\hline & $50.34 \pm 3.02 \mathrm{~b} *$ & $43.75 \pm 0.96 \mathrm{~b}$ & $49.66 \pm 0.73 \mathrm{a}$ & $12.98 \pm 1.17 \mathrm{a}$ \\
PAS & $51.27 \pm 2.10 \mathrm{~b}$ & $44.66 \pm 1.90 \mathrm{~b}$ & $49.40 \pm 0.97 \mathrm{ab}$ & $11.70 \pm 0.91 \mathrm{a}$ \\
PAE & $54.48 \pm 1.36 \mathrm{a}$ & $47.54 \pm 1.03 \mathrm{a}$ & $48.40 \pm 1.03 \mathrm{~b}$ & $11.76 \pm 1.52 \mathrm{a}$ \\
PAF & 4.24 & 3.01 & 1.86 & 10.06 \\
\hline CV (\%) & & a & &
\end{tabular}

Means followed by the same lower case letter in the column are not different by Tukey test $(P<0.01)$.

* Mean \pm standard deviation 
The dry matter concentration in the non-wilted (25\%) and wilted (27.7\%) aerial part was not limiting to fermentation (Table 4). Wilting the aerial part of the cassava plants resulted in an increase in DM concentration in the order of $10.8 \%$, which is considered low. Nussio (1991) cited a minimum DM concentration range of 25 to $27 \%$ for the material to be properly ensiled so that the dry matter concentration will not interfere with the fermentation process within the silo. The small water loss verified for the cassava aerial part, under wilting, was due to the climatic conditions during the period, which consisted of partially cloudy sky, in association with the stem's rigidity and waxiness, which made water loss difficult. However, these concentrations (25.0 and 27.7\% DM) are low when compared with those for maize plants, which are considered a standard for ensiling, where the ideal cutting time occurs when the plants show between 33 and 37\% dry matter (Silveira, 1975).

The buffer capacity (BC) of materials destined to ensiling is one of the characteristics that determine the passage from an initial butyric fermentation to the quick establishment of lactic fermentation organisms, which confer desirable characteristics to the silage. The BC obtained for the non-wilted (2045 mmol kg-1 DM) and wilted (1904 mmol kg $\mathrm{kg}^{-1} \mathrm{DM}$ ) cassava aerial parts allowed for a fast decline in $\mathrm{pH}$ in the ensiled mass, inhibiting acetic and butyric fermentation. The values are very similar to those for maize plants, according to data by Creste (2000). The soluble carbohydrate concentrations (CHOs) in the fresh aerial part (33\% of DM), as well as in the wilted material (35.5\% of DM) were similar and can considered high, providing a substrate for the growth of lactic bacteria. The CHOs concentrations found were higher than the 15\% reported by Johnson et al. (1971) and Obeid et al. (1992) as the minimum concentration of dry matter for fermentation. Catchpoole \& Henzel (1971) concluded that this concentration, associated with the production of lactic silages from tropical plants should be between 13 and $16 \%$ in the dry matter.

Table 4 - Dry matter, and soluble carbohydrate concentrations, and buffer capacity (BC) of non-wilted (PAS) and wilted (PAE) aerial part of cassava.

\begin{tabular}{lccc}
\hline Item & \multicolumn{2}{c}{ Treatment } & CV \\
\hline \multicolumn{1}{c}{ PAS } & PAE & $\%$ \\
$\begin{array}{l}\text { Dry matter (\%) } \\
\begin{array}{l}\text { Soluble } \\
\text { carbohydrates } \\
(\% D M)\end{array}\end{array}$ & $25.0 \pm 0.76 \mathrm{~b}^{*}$ & $27.7 \pm 0.36$ a & 1.07 \\
$\begin{array}{l}\text { BC } \\
\left(\mathrm{mmol} \mathrm{kg}{ }^{-1} \mathrm{DM}\right)\end{array}$ & $2045 \pm 392 \mathrm{a}$ & $35.53 \pm 3.92$ a & 10.51 \\
\hline
\end{tabular}

Means followed by the same lower case letter in the row are not different by Tukey test $(P<0.01)$.

*Mean \pm standard deviation
The CHOs concentration should not be considered individually; instead, the $\mathrm{CHO}$ : $\mathrm{BC}$ ratio in the material should be taken into account. Munck (1988) stated that the higher this ratio, the smaller the final $\mathrm{pH}$ of the silage. Leibensperger \& Pitt (1988); cited by Creste, 2000), stated that this ratio is dependent upon the DM concentration, and that increased DM concentration would cause the ratio to increase, favoring the fermentation process and inhibiting the activity of bacteria of the genus Clostridium.

Wilting resulted in no $\mathrm{pH}$ response, with values of 3.57 and 3.60 in non-wilted and wilted ensiled materials, respectively (Table 5), contrary to observations by Woolford (1984), who found that a silage made from a forage that had been subjected to wilting was stable under a lower $\mathrm{pH}$ value. This, again, provides evidence that a small water loss does not lead to changes in the fermentation patterns of the aerial part of cassava. Silages with a pH lower than 4.6 can be considered excellent (Ruiz \& Ruiz, 1990).

Ammonia-nitrogen $\left(\mathrm{N}-\mathrm{NH}_{3}\right)$ works as an important indicator of proteolytic activity during the fermentation process. The concentration of $\mathrm{N}^{-\mathrm{NH}_{3}}$ was $6.57 \%$ of the total $\mathrm{N}$ in PAS and $13 \%$ in PAE. The PAS silage can be considered excellent, since it showed an ammonia-nitrogen concentration of up to 8\% (Ruiz \& Ruiz, 1990). The ammonia concentrations must not be higher than $11-12 \%$ of total nitrogen, in well-preserved silages (Silveira, 1975). The $\mathrm{N}-\mathrm{NH}_{3}$ concentration found in PAE silage was higher and provides evidence that, even though the material had a high CHOs concentration, a low buffer capacity, and an adequate dry matter concentration, degradation of amino acids by bacteria of the genus Clostridium did occur. Nussio \& Manzano (1999) cited that the action of proteolytic enzymes can occur when the material has a reduced rate of dehydration, as is the case for the aerial part of cassava.

The proportion of total nitrogen retained in the acid detergent insoluble nitrogen fraction (ADIN) (Table

Table 5 - Fermentation quality of silages made without wilting (PAS) and with wilting (PAE), and of hay (PAF), from the aerial part of cassava: hydrogen potential $(\mathrm{pH})$, ammonia-nitrogen $\left(\mathrm{N}-\mathrm{NH}_{3}\right)$ and acid detergent insoluble nitrogen (ADIN) concentrations.

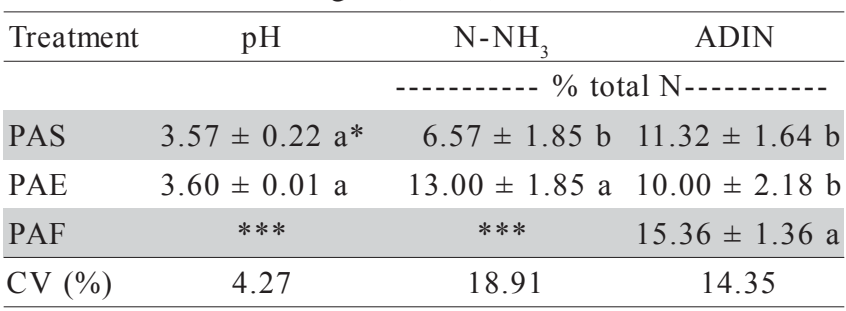

Means followed by the same lower case letter in the column are not different by Tukey test $(P<0.01)$.

$*$ Mean \pm standard deviation 
Table 6 - Organic acid profiles in fresh and wilted silages from the aerial part of cassava in acetic, lactic, propionic, and butyric acid.

\begin{tabular}{|c|c|c|c|c|}
\hline Treatment & Acetic & Lactic & Propionic & Butyric \\
\hline & (n) & . & - & (n) \\
\hline Non-wilted silage & $0.23 \pm 0.02 \mathrm{a}^{*}$ & $5.06 \pm 0.69 \mathrm{a}$ & $0.07 \pm 0.02 \mathrm{a}$ & $0.55 \pm 0.07 \mathrm{a}$ \\
\hline Wilted silage & $0.33 \pm 0.03 \mathrm{~b}$ & $5.51 \pm 0.38 \mathrm{a}$ & $0.11 \pm 0.02 \mathrm{a}$ & $0.49 \pm 0.07 \mathrm{a}$ \\
\hline CV (\%) & 25.67 & 25.22 & 49.60 & 33.77 \\
\hline
\end{tabular}

Means followed by the same lower case letter in the column are not different by Tukey test $(P<0.01)$.

*Mean \pm standard deviation

5) is an important indicator that the material overheated before the fermentation was stabilized. PAE resulted in a silage with $10 \%$ of total $\mathrm{N}$ in the form of ADIN while PAS showed $11.32 \%$ of total $\mathrm{N}$ as ADIN; these values being not different. Thus, both silages can be considered acceptable, since Roth \& Undersander (1995) proposed a $12 \%$ ADIN limit for well-prepared corn silages. In hay, the ADIN concentration ( $15.35 \%$ of total $\mathrm{N}$ ) was higher than in the silages, indicating heating caused by aerobic bacteria and fungi, mainly due to the difficulty of the material in losing moisture quickly, even though the aboveground part of the plant had been chopped.

The organic acid concentrations (Table 6) found in the silages from the non-wilted and wilted aerial part of cassava were equal. However, the silage from the material with a higher moisture concentration (PAS) showed greater variability in lactic acid concentrations than those found in the silage from the wilted material (PAE), indicating lower fermentation efficiency in the non-wilted material.

The acetic acid concentrations were 0.23 and $0.33 \%$ in the non-wilted and wilted silages, respectively, and greater variation occurred in the wilted silage. Such high variation in acetic acid concentrations was also observed by Tosi (1973); Silveira et al. (1979); Lavezzo et al. (1983); Machado Filho \& Mühlbach (1986) and Alberto et al. (1993).

Lactic acid participated with a mean $5.3 \%$ of the PAS and PAE silage juice. These contents fall within the interval proposed by Catchpoole \& Henzel (1971), from 3 to $13 \%$ of lactic acid in the silage juice. The lactic/acetic ratio is especially important to allow for comparisons and inferences between two fermentation processes. This ratio showed large differences between the ensiled materials; the non-wilted silage had a 21.82 ratio, while the PAE silage showed a 16.88 ratio. Despite the fact that the lactic acid concentrations did not indicate differences, the lactic/acetic ratio suggests that there is a higher activity of lactic bacteria with regard to coliforms in PAS, in relation to PAE. Wilting reduced the performance of the lactic acid-producing bacteria by about $22 \%$.

The propionic acid concentrations were 0.07 and 0.11\% for PAS and PAE, respectively, considered well within the interval detected by Lavezzo et al. $(1983 ; 1990)$,
Table 7 - Cyanohydrin (Total hydrocyanic acid) and HCN (free hydrocyanic acid) concentrations in the aerial part of cassava.

\begin{tabular}{lcc}
\hline Treatment & Total & Free \\
\hline Non-wilted aerial part & $25.90 \pm 5.67 \mathrm{a}^{*}$ & $7.00 \pm 1.36 \mathrm{a}$ \\
Wilted aerial part & $27.50 \pm 4.65 \mathrm{a}$ & $7.37 \pm 0.88 \mathrm{a}$ \\
Non-wilted silage & $28.22 \pm 6.80 \mathrm{a}$ & $1.48 \pm 0.23 \mathrm{~b}$ \\
Pre-wilted silage & $29.18 \pm 6.58 \mathrm{a}$ & $1.86 \pm 0.25 \mathrm{~b}$ \\
\hline CV $(\%)$ & 21.60 & 18.61
\end{tabular}

Means followed by the same lower case letter in the column are not different by Tukey test $(P<0.01)$.

*Mean \pm standard deviation

from 0.06 to $0.23 \%$ in elephantgrass (Pennisetum purpureum Schum.) silage. The butyric acid concentration is an important indicator of proteolytic activity in the material; it was the same in both the PAS and PAE silages, contrary to Woolford (1984), who reported that a lower activity of bacteria of the genus Clostridium occurs in silages with a higher dry matter concentration. The absence of differences could be associated with the reduced water loss that resulted from wilting. The butyric acid concentrations of 0.55 and $0.49 \%$ found in PAS and PAE silages are above the $0.2 \%$ concentration of DM proposed by Silveira (1975) as the limit for good quality silages. The silages from the aerial part of cassava are classified as non-satisfactory with regard to butyric acid concentrations (Lavezzo, 1985).

One factor that may limit the use of cassava for animal nutrition, especially with reference to its aerial part, is its cyanogenic principle, measured as free hydrocyanic acid concentration (HCN), which might be deadly. Ensiling reduced the concentrations of free hydrocyanic acid, which were 7.00 and $7.37 \mathrm{mg} \mathrm{kg}^{-1}$ in PAS and PAE, respectively (Table 7), down to $1.48 \mathrm{mg} \mathrm{kg}^{-1}$ in the PAS silage and to $1.86 \mathrm{mg} \mathrm{kg}^{-1}$ in PAE silage, representing 78.84 and $74.70 \%$ of elimination of the toxic principle during the ensiling process of PAS and PAE, respectively. The process of grinding and subsequently heating the material during fermentation could help break the cyanogenic compounds present in the aerial part of cassava. These results are in agreement with those of Carvalho 
Table 8 - Total Digestible Nutrients (TDN), Dry Matter “In Vitro” True Digestibility (IVTD) and Soluble Nitrogen (Nsol.) concentrations.

\begin{tabular}{lccc}
\hline Treatment & TDN & IVTD & Nsol. \\
\hline & --1.29 total N \\
Non-wilted aerial part & $49.38 \pm 1.29 \mathrm{~b}^{*}$ & $68.90 \pm 0.95 \mathrm{ab}$ & $18.69 \pm 5.08 \mathrm{c}$ \\
Wilted aerial part & $49.20 \pm 1.58 \mathrm{~b}$ & $70.21 \pm 0.54 \mathrm{a}$ & $23.22 \pm 5.58 \mathrm{bc}$ \\
Aerial part made into hay & $52.04 \pm 0.70 \mathrm{a}$ & $66.67 \pm 0.24 \mathrm{~b}$ & $18.19 \pm 5.35 \mathrm{c}$ \\
Non-wilted silage & $* * *$ & $67.58 \pm 1.14 \mathrm{~b}$ & $31.52 \pm 5.66 \mathrm{ab}$ \\
Pre-wilted silage & $* * *$ & $68.14 \pm 0.99 \mathrm{ab}$ & $38.00 \pm 5.07 \mathrm{a}$ \\
\hline $\mathrm{CV}(\%)$ & 78.48 & 1.23 & 20.64 \\
\hline
\end{tabular}

Means followed by the same lower case letter in the column are not different by Tukey test $(\mathrm{P}<0.01)$.

*Mean \pm standard deviation

(1990, cited by Buitrago, 1990), who also observed a decline in free HCN concentrations when the aerial part of cassava was ensiled. The total hydrocyanic acid concentration (cyanohydrin) did not change with the ensiling process. This compound is not readily toxic when ingested, but has a potential for releasing cyanide when exposed to conditions that are favorable to hydrolysis. With regard to linamarin, not even traces were found in any of the ensiled materials, suggesting that its partial hydrolysis occurs immediately when the material is chopped, and only the intermediate product (cyanohydrin) remains.

A commonly used index to evaluate food for ruminants is TDN (Table 8), which is obtained by the weighted sum of all fractions utilized by the animal during the digestive process. The TDN concentrations in PAS, PAE and PAF were 49.38; 49.20 and $52.03 \%$ respectively. The material made into hay was better than the other two, which were equivalent. This is due to the higher ether extract concentration obtained for the material made into hay, because even not showing differences in relation to the other materials, was sufficient to increase TDN concentration, since the calculation formula assigns a greater weight to EE. One analysis that supplements TDN concentration determination is dry matter in vitro true digestibility (IVTD), which is a more reliable information, because it is obtained by simulation of the animal's digestive process and not only by an estimate based on calculations such as TDN. Contrary to the TDN results, the materials that showed the best nutritive value were PAE (70.20\%) and PAS (68.90\%), without differences, while PAF was the material with the lowest IVTD (66.67\%), reflected by its higher fiber concentration (Tables 2 and 3). IVTD in PAS and PAE did not differ from their respective silages, whose values were 67.57 and $68.13 \%$, respectively. The superiority of materials analyzed fresh or ensiled, over the material made into hay is possibly due to the oxidation processes which occurred to a greater extent in hay than in the silages or in fresh material, since respiration was absent due to anaerobiosis (silage) or dehydration (fresh).
The soluble nitrogen concentrations ( $\%$ total $\mathrm{N}$ ) was not different between the materials that did not undergo the fermentation process; PAS, PAE and PAF resulted, respectively, in 18.69; 23.22 and $18.18 \% \mathrm{~N}_{\text {sol. }}$ of total $\mathrm{N}$ in the $\mathrm{DM}$, but fermentation caused higher $\mathrm{N}_{\text {sol. }}$. concentration both in PAS (31.52\%) and PAE silage (38.00\%). This increase confirms the result for $\mathrm{N}-\mathrm{NH}_{3}$, in which PAE silage was also superior to PAS silage. Based on this superiority of $\mathrm{N}_{\text {sol. }}$ values in relation to $\mathrm{N}$ $\mathrm{NH}_{3}$, it can be inferred that the other $\mathrm{N}_{\text {sol. }}$ forms, in addition to $\mathrm{N}-\mathrm{NH}_{3}$, were present in the silages. In spite of the difference for $\mathrm{N}_{\text {sol. }}$, the extent of solubilization is practically the same for the forage ensiling processes: 12.80 points for non-wilted silage and 14.80 points for wilted silage.

\section{CONCLUSIONS}

Processing the aerial part of cassava for animal feeding can be interesting, especially when introduced to production systems for small and medium-sized properties. Despite the fact that the aerial part of cassava does not have any conservation problems as silage or hay, its use in animal nutrition is still very little studied and known in Brazil. In larger-sized systems its adoption will depend upon the feasibility of mechanized harvest and conservation of the cassava plant.

\section{REFERENCES}

ALBERTO, G.; PORTELA, J.S.; OLIVEIRA, O.L.P. Efeito da adição de grão de sorgo moído e do emurchecimento sobre a qualidade de silagem de capim-elefante (Penissetum purpureum, Schum.) Revista da Sociedade Brasileira de Zootecnia, v.22, p.1-11, 1993.

BATISTINI, C.R.; FEITOSA TELES, F.F.; COELHO, D.T. Determinação de toxicidade cianogênica e carboidratos solúveis totais em cultivares de mandioca (Manihot esculenta Crantz.) Revista Ceres, v.28, p.521-525, 1981.

BOIN, C. Elephant grass (napier) silage production: effect of addition on chemical composition, nutritive value and animal performance. Ithaca: Cornell University, 1975. 215p. (Thesis - Ph.D.).

BUITRAGO A., J.A. La yuca em la alimentación animal. Cali: CIAT, 1990. 446p.

CARVALHO, J.L.H. de A mandioca: raiz e parte aérea na alimentação animal. Brasília: EMBRAPA, CPAC, 1990. 
CATCHPOOLE, V.R.; HENZEL, E.F. Silage and silage-making from tropical herbage species. Herbage Abstracts, v.41, p.213-221, 1971.

CENTRO INTERNACIONAL DE AGRICULTURA TROPICAL. Sistema de producción de ganado porcino. Cali: CIAT, 1974. (Informe Anual).

CONCEIÇÃO, A.J. A mandioca. São Paulo: Nobel, 1981. 382p.

CRESTE, C.R. Potencial para ensilagem, composição bromatológica e qualidade da silagem de milho com diferentes proporções de espigas. Botucatu: UNESP/FMVZ, 2000. 27p. (Dissertação - Mestrado).

DUBOIS, M.; GILLES, K.A.; HAMILTON, J.K. Calorimetric method for determination of sugars and related substances. Analytical Chemistry, v.28, p.350-356, 1956.

D’UTRA, G.P. A mandioca como forragem. Boletim do Instituto Agronômico do Estado de São Paulo, v.10, p.196-207, 1899.

ESSERS, A.J.A.; BOSVELD, M.; VAN DER GRIFT, R.M.; VORAGEN, A.G.J.; Studies on the quantification of specific cyanogens in cassava products and introduction of a new chromogen. Journal of Science and Food Agriculture, v.63, p.287-296, 1993.

FNP CONSUlTORIA E COMÉRCIO. Agrianual 2002. São Paulo, 2002. 389p.

JOHNSON, R.R.; FARIA, U.P.; McCLURE, K.E. Effects of maturity of chemical composition and digestibility of bird resistant sorghum plants when fed to sheep as silage. Journal of Animal Science, v.33, p.1102-1109, 1971.

KEARL, L.C. Nutrient requirements of ruminants in developing countries. Logan: International Feedstuffs Institute, Utah State University, 1971.

LAVEZZO, W. Silagem de capim-elefante. Informe Agropecuário, v.11, p.50-57, 1985.

LAVEZZO, W.; GUTIERRES, L.C.; SILVEIRA, A.C. Utilização do capim-elefante (Penissetum purpureum, Schum.), cultivares Mineiro e Vruckwona como planta para ensilagem. Revista da Sociedade Brasileira de Zootecnia, v.12, p.163-176, 1983.

LAVEZZO, W.; LAVEZZO, O.E.N.M.; BONASSI, I.A. Efeito do emurchecimento, formol, ácido fórmico, e solução de "Viher"sobre a qualidade de silagens de capim-elefante, cultivares Mineiro e Vruckwona. Pesquisa Agropecuária Brasileira, v.25, p.125134, 1990.

LEIBENSPERGER, R.Y.; PITT, R.E. Modeling the effects of formic acid and malasses on ensilage. Journal of Dairy Science, v.71, p.1220-1231, 1988.

MACHADO FILHO, L.C.P.; MÜHLBACH, P.R.F. Efeito do emurchecimento na qualidade das silagens de capim-Elefante cv. Cameron (Penissetum purpureum, Schum.) e de milheto (Pennisetum americanum (L.) Leeke), avaliadas quimicamente. Revista da Sociedade Brasileira de Zootecnia, v.15, p.224233, 1986.

MISCHAN, M.M.; PINHO, S.Z. Experimentação agronômica Dados não-balanceados. Botucatu: Fundibio, 1996. 456p.
MUNCH, R.E. Factors influencing silage quality and their implications for manegement. Journal of Dairy Science, v.71, p.2992-3002, 1988.

NORMANHA, E.S. As folhas de mandioca servem como alimento. O Estado de São Paulo. Suplemento Agrícola, São Paulo, 9-março, 1966.

NUSSIO, L.G. Milho e sorgo para produção de silagem. In: PRODUÇÃO DE ALIMENTOS VOLUMOSOS PARA BOVINOS, Piracicaba, 1991. Anais. Piracicaba: FEALQ, 1991. p.75-177.

NUSSIO L.G.; MANZANO R.P. Valor nutritivo e conservação. In: SIMPÓSIO SOBRE MANEJO DA PASTAGEM: ALFAFA, Piracicaba, 1999. Anais. Piracicaba: FEALQ, p.153-173.

OBEID, J.A.; GOMIDE, J.A.; CRUZ, M.E. Silagem consorciada de milho (Zea mays, L) com leguminosas: produção e composição bromatológica. Revista da Sociedade Brasileira de Zootecnia, v.21, p.33-38, 1992.

PLAYNE, M.J.; McDONALD, P. The buffering constituents of herbage. Journal of the Science of Food and Agriculture, v.17, p.264268, 1966

ROTH, G.; UNDERSANDERS, D. Silage additives. In: ALLEN, M.; FORD, S.; HARRISON, J.; HUNT, C.; LAUER, J.; MUNCK, R.; ROTH, G.; SADERLUND, S.; UNDERSANDER, D. Corn silage production management and feeding. Madison: ASA, 1995. p.27-29.

RUIZ, E.M.; RUIZ, A. Metodologías para investigaciones sobre conservación y utilización de silagens. In: INSTITUTO INTERAMERICANO DE COOPERACIÓN PARA LA AGRICULTURA. Nutrición de ruminantes: guia metodológico de cooperación. San José: IICA, 1990. p.179-218.

SILVEIRA, A.C. Técnica para produção de silagem. In: SIMPÓSIO SOBRE MANEJO DE PASTAGENS, 2, Piracicaba, 1975. Anais. Piracicaba: FEALQ, 1975. p.156-186.

SILVEIRA A.C.; LAVEZZO, W.; TOSI, H. Avaliação química de silagens de capim-Elefante (Penissetum purpureum, Schum.) submetidas a diferentes tratamentos. Revista da Sociedade Brasileira de Zootecnia, v.8, p.287-300, 1979.

VAN SOEST, P.J. Nutrition ecology of the ruminant. 2.ed. Ithaca: Cornell University Press, 1994. 476p.

TOSI, H. Ensilagem de gramíneas tropicais sob diferentes tratamentos. Botucatu: UNESP/FCAB, 1973. 107p. (Tese - Doutorado).

WINKINS, R.J.; HUTCHINSON, K.J.; WILSON, R.F. The voluntary intake of silage by sheep. I. Interrelation between silage composition and intake. Journal of Agricultural Science, v.77, p.531-537, 1971.

WOOLFORD, M.K. The silage fermentation. New York: Marcel Dekker, 1984. 350p.

Received August 21, 2003

Accepted April 23, 2004 